\title{
P2X7-Dependent Release of Interleukin-1 $\beta$ and Nociception in the Spinal Cord following Lipopolysaccharide
}

\author{
Anna K. Clark, Amelia A. Staniland, Fabien Marchand, Timothy K. Y. Kaan, Stephen B. McMahon, \\ and Marzia Malcangio \\ Neurorestoration Group, Wolfson Centre for Age-Related Diseases, King's College London, London SE1 1UL, United Kingdom
}

The cytokine interleukin- $1 \beta$ (IL-1 $\beta$ ) released by spinal microglia in enhanced response states contributes significantly to neuronal mechanisms of chronic pain. Here we examine the involvement of the purinergic P2X7 receptor in the release of IL-1 $\beta$ following activation of Toll-like receptor-4 (TLR4) in the dorsal horn, which is associated with nociceptive behavior and microglial activation. We observed that lipopolysaccharide (LPS)-induced release of IL-1 $\beta$ was prevented by pharmacological inhibition of the P2X7 receptor with A-438079, and was absent in spinal cord slices taken from P2X7 knock-out mice. Application of ATP did not evoke release of IL-1 $\beta$ from the dorsal horn unless preceded by an LPS priming stimulus, and this release was dependent on P2X7 receptor activation. Extensive phosphorylation of p38 MAPK in microglial cells in the dorsal horn was found to correlate with IL-1 $\beta$ secretion following both LPS and ATP. In behavioral studies, intrathecal injection of LPS in the lumbar spinal cord produced mechanical hyperalgesia in rat hindpaws, which was attenuated by concomitant injections of either a nonspecific (oxidized ATP) or a specific (A-438079) P2X7 antagonist. In addition, LPS-induced hypersensitivity was observed in wild-type but not P2X7 knock-out mice. These data suggest a critical role for the P2X7 receptor in the enhanced nociceptive transmission associated with microglial activation and secretion of IL-1 $\beta$ in the dorsal horn. We suggest that CNS-penetrant P2X7 receptor antagonists, by targeting microglia in pain-enhanced response states, may be beneficial for the treatment of persistent pain.

\section{Introduction}

The term "neuroinflammation" defines specific physiological and pathological phenomena associated with trafficking of immune cells in the CNS with both beneficial and detrimental effects (Medzhitov, 2008). Specifically, inflammation of the lumbar spinal cord following traumatic injury, or peripheral nerve injury, shows unique features associated with pain. These include the transition of microglia and astrocytes to pain-enhanced response states, as well as immune cell infiltration, in the vicinity of the synapse between primary afferent fibers and second-order nociceptive neurons in the dorsal horn of the spinal cord (Abbadie et al., 2009; Milligan and Watkins, 2009).

In particular, microglial cells in enhanced response states release many proinflammatory mediators, such as the cytokine IL- $1 \beta$, which can modulate neuronal mechanisms of chronic pain in the dorsal horn (McMahon and Malcangio, 2009). For example, the acute activation of microglial TLR4 by intrathecal lipopolysaccharide (LPS) is associated with pain, and ex vivo activation of microglial TLR4 in the dorsal horn induces rapid release of IL- $1 \beta$ alongside caspase- 1 , and its accessory protein ASC

\footnotetext{
Received July 10, 2009; revised Nov. 23, 2009; accepted Dec. 1, 2009.

This work is funded by the Wellcome Trust. A.A.S. was supported by the Arthritis Research Campaign. P2X7 - / mice were generously provided by GlaxoSmithKline.

Correspondence should be addressed to Dr. Marzia Malcangio, Wolfson Centre for Age-Related Diseases, King's College London, Wolfson Wing, Hodgkin Building, Guy's Campus, London SE1 1UL, UK. E-mail: marzia. malcangio@kcl.ac.uk.

F. Marchand's present address: Inserm/UdA 766 Pharmacologie Fondamentale et Clinique de la douleur, Faculté de Médecine, 28 Place Henri Dunant, 63000 Clermont-Ferrand, France.

DOI:10.1523/JNEUROSCI.3295-09.2010

Copyright $\odot 2010$ the authors $\quad 0270-6474 / 10 / 300573-10 \$ 15.00 / 0$
}

(Clark et al., 2006). Indeed, intrathecal injection of IL-1 $\beta$ is pronociceptive (Reeve et al., 2000; Sung et al., 2004), and increases both dorsal horn neuron excitability (Reeve et al., 2000; Gustafson-Vickers et al., 2008) and the release of primary afferent excitatory neurotransmitters (Malcangio et al., 1996). Genetic impairment of IL- $1 \beta$ signaling attenuates nerve-injury-induced pain behaviors (Honore et al., 2006a; Wolf et al., 2006). Furthermore, intrathecal delivery of the IL- $1 \beta$ receptor antagonist prevents hyperalgesia associated with acute microglial activation following intrathecal LPS, via activation of TLR4 (Clark et al., 2006).

In addition to TLR4, for which the endogenous agonist remains unidentified, spinal microglial cells express receptors for endogenous ligands associated with nociception such as the purinergic P2X receptors for ATP (Burnstock, 2006). In particular $\mathrm{P} 2 \mathrm{X} 7$ plays a critical role in IL- $1 \beta$ processing and release from LPS-primed macrophages (Ferrari et al., 2006) via two distinct caspase-1-dependent and independent pathways (Pelegrin et al., 2008). Interestingly, $P 2 X 7$ receptor knock-out mice develop reduced inflammatory hyperalgesia, and LPS-primed macrophages from these mice do not secrete IL- $1 \beta$ (Chessell et al., 2005), supporting the possibility that $\mathrm{P} 2 \mathrm{X} 7$ receptors contribute to pain associated with inflammation by modulating the release of proinflammatory cytokines from macrophages (Chessell et al., 2005). However, the findings that $P 2 X 7$ knock-out mice develop reduced hyperalgesia following peripheral nerve injury (Chessell et al., 2005), and that P2X7 antagonists attenuate neuropathic pain behavior (McGaraughty et al., 2007), can only be partially reconciled with impaired release of IL- $1 \beta$ from infiltrating macrophages at the site of nerve damage. Indeed, depletion of 
peripheral macrophages only partially reduces neuropathic hyperalgesia (Rutkowski et al., 2000; Barclay et al., 2007).

Thus, we evaluated whether spinal P2X7 receptors contributed to nociceptive mechanisms associated with microglial release of IL- $1 \beta$. First, we evaluated whether spinal P2X7 receptors modulated LPS-induced IL- $1 \beta$ release from microglia in the dorsal horn of the spinal cord. Second, we assessed the contribution of spinal P2X7 to LPS-induced mechanical hypersensitivity.

\section{Materials and Methods \\ Animals}

Experiments were performed using male Wistar rats and adult mice of both sexes ( $>8$ weeks of age) in accordance with United Kingdom Home Office regulations. $P 2 X 7$ knock-out mice and wild-type littermates were produced by breeding from heterozygous pairs to give litters of mixed genotypes $(+/+$, wild-type; $+/-$, heterozygous; $-/-$, knock-out). Disruption of target genes was confirmed using PCR with standard agarose gel electrophoresis. The generation of this $P 2 X 7$ knock-out strain has been previously described (Chessell et al., 2005).

\section{Release of IL-1 $\beta$ from dorsal horn slices}

Horizontal dorsal horn slices with dorsal roots attached were obtained as previously described (Clark et al., 2006, 2009), from the lumbar spinal cord of adult rats, and from $P 2 X 7$ knock-out and wild-type mice. Briefly, lumbosacral spinal cord was excised and longitudinally hemisected producing a horizontal slice with L4 and L5 dorsal roots attached. One slice was obtained from each rat or mouse, mounted in the central compartment of a three compartment chamber and continuously superfused $(1 \mathrm{ml} / \mathrm{min})$ with oxygenated $\left(95 \% \mathrm{O}_{2}+5 \% \mathrm{CO}_{2}\right)$ Krebs' solution (in $\mathrm{mol} / \mathrm{L}: \mathrm{NaCl}, 118 ; \mathrm{KCl}, 4 ; \mathrm{MgSO}_{4}, 1.2 ; \mathrm{KH}_{2} \mathrm{PO}_{4}, 1.2 ; \mathrm{NaHCO}_{3}, 25 ; \mathrm{CaCl}_{2}$, 2.5; and glucose, 11 ) containing $0.1 \%$ bovine serum albumin (BSA) and $20 \mu \mathrm{g} / \mathrm{ml}$ bacitracin to minimize protein degradation. The dorsal roots were placed in the lateral compartments and immersed in mineral oil to avoid dehydration. Before, during, and after chemical stimulation, fractions of $8 \mathrm{ml}$ of the superfusates were collected from the central compartment in ice-chilled glass tubes to minimize IL- $1 \beta$ loss.

Experiment 1: lipopolysaccharide-induced release of $I L-1 \beta$ from the rat dorsal horn. Lipopolysaccharide (LPS, Escherichia coli; Sigma) was solubilized in $\mathrm{H}_{2} \mathrm{O}(10 \mathrm{mg} / \mathrm{ml})$ and then diluted in Krebs' solution and superfused $(10 \mu \mathrm{g} / \mathrm{ml}$ for $8 \mathrm{~min})$ through naive dorsal horn slices as previously described (Clark et al., 2006, 2009). Three $8 \mathrm{ml}$ fractions were collected before stimulation ( $0-24 \mathrm{~min})$ to measure basal levels of IL-1 $\beta$. These values were then pooled and expressed as "basal." One fraction was collected during LPS superfusion (24-32 $\mathrm{min}$ ), and four fractions after LPS to assess recovery to basal levels of IL-1 $\beta$ (R1, 32-40 min; R2, 40 -48 min; R3, 48-56 min; R4, 56-64 min).

Experiment 2: pharmacological modulation of LPS-induced release of $I L-1 \beta$ in rat dorsal horn. LPS was superfused $(10 \mu \mathrm{g} / \mathrm{ml}$ for $8 \mathrm{~min})$ through naive dorsal horn slices. Pharmacological manipulation of IL- $1 \beta$ release was achieved by superfusion of the specific P2X7 antagonist A-438079 (10 $\mu \mathrm{M}$; Tocris Bioscience) in one fraction before and during LPS superfusion (16 min in total).

Experiment 3: ATP-induced release of $I L-1 \beta$ in rat dorsal horn. Rats received an intrathecal priming dose of either LPS ( $2 \mu \mathrm{g} / 10 \mu \mathrm{l}$ per rat) or vehicle $(0.9 \%$ saline) $24 \mathrm{~h}$ before obtaining the dorsal horn slice. ATP (Sigma) was solubilized in Krebs' solution and superfused (1 mm for 8 min) through dorsal horn slices. Three $8 \mathrm{ml}$ fractions were collected before stimulation $(0-24 \mathrm{~min})$ to measure basal levels of IL-1 $\beta$. One fraction was collected during ATP superfusion (24-32 min), and four fractions after ATP to assess recovery to basal levels of IL-1 $\beta$ (R1, 32-40 min; R2, 40-48 min; R3, 48-56 min; R4, 56-64 min). The adenosine receptor antagonist 8 -(p-sulfophenyl)-theophylline (10 $\mu \mathrm{M}$; Sigma) was added to the superfusion solution 8 min before ATP, to prevent adenosine receptor activation following ATP hydrolysis.

Experiment 4: pharmacological modulation of ATP-induced release of $I L-1 \beta$ in rat dorsal horn. Rats received an intrathecal priming dose of LPS $(2 \mu \mathrm{g} / 10 \mu \mathrm{l}$ per rat) $24 \mathrm{~h}$ before obtaining the dorsal horn slice. ATP was superfused (1 mM for $8 \mathrm{~min}$ ) through spinal cord slices. Pharmacological manipulation of IL- $1 \beta$ release was achieved by superfusion of the specific P2X7 antagonist A-438079 (10 $\mu \mathrm{M}$; Tocris Bioscience) in one fraction before and during ATP superfusion (16 min in total).

Experiment 5: LPS-induced release of IL-1 $\beta$ from the dorsal horn of P2X7 knock-out and wild-type mice. LPS was superfused ( $10 \mu \mathrm{g} / \mathrm{ml}$ for $8 \mathrm{~min})$ through dorsal horn slices obtained from P2X7 knock-out and wild-type mice of both sexes. Three $8 \mathrm{ml}$ fractions were collected before stimulation $(0-24 \mathrm{~min})$ to measure basal levels of IL-1 $\beta$. One fraction was collected during LPS superfusion (24-32 $\mathrm{min}$ ), and four fractions after LPS to assess recovery to basal levels of IL- $1 \beta$ (R1, 32-40 min; R2, 40-48 min; R3, 48-56 min; R4, 56-64 min).

Experiment 6: ATP-induced release of $I L-1 \beta$ from the dorsal horn of P2X7 knock-out and wild-type mice. P2X7 knock-out and wild-type mice received an intrathecal priming dose of LPS ( $2 \mu \mathrm{g} / 5 \mu \mathrm{l}$ per mouse) $24 \mathrm{~h}$ before obtaining the spinal cord slice. ATP was superfused ( $1 \mathrm{~mm}$ for 8 min) through dorsal horn slices. Three $8 \mathrm{ml}$ fractions were collected before stimulation $(0-24 \mathrm{~min})$ to measure basal levels of IL- $1 \beta$. One fraction was collected during ATP superfusion (24-32 min), and four fractions after ATP to assess recovery to basal levels of IL-1 $\beta$ (R1, 32-40 min; R2, 40-48 min; R3, 48-56 min; R4, 56-64 min).

\section{$I L-1 \beta$ ELISA}

To quantify IL- $1 \beta$ content in superfusates, $8 \mathrm{ml}$ samples were desalted and concentrated by Ultrafree- $1510 \mathrm{~K}$ centrifugal device (Millipore). Retentates were lyophilized, reconstituted in $150 \mu$ l of sample buffer (R\&D Systems) and assayed for IL- $1 \beta$ content by ELISA. Ninety-six-well colorimetric "sandwich" ELISA plates (R\&D Systems, IL-1 $\beta / \mathrm{IL}-1 \mathrm{~F} 2$ Quantikine ELISA Kit) were used to determine IL- $1 \beta$ content. Rat recombinant IL- $1 \beta$ standards (50 $\mu \mathrm{l}$ of $2000-15.6 \mathrm{pg} / \mathrm{ml})$ and $50 \mu \mathrm{l}$ of unknown samples were run in duplicate following the manufacturers' instructions. The optical density of each well was determined at a wavelength of $450 \mathrm{~nm}$. Samples were considered IL-1 $\beta$ positive when the signal was higher than background signal (modified Krebs' solution) and within the range of the standard curve. Data are expressed as percentage of IL- $1 \beta$ content in the basal fractions.

\section{Release of ATP from dorsal horn slices}

Horizontal dorsal horn slices were obtained from the lumbar spinal cord of P2X7 knock-out and wild-type mice as described above. Slices were then chopped into microprisms ( $350 \mu \mathrm{m} \times 350 \mu \mathrm{m}$ cubes) using a tissue chopper. Microprisms from two slices of either wild-type or knock-out mice were placed into each Eppendorf tube, immediately dispersed in 1 $\mathrm{ml}$ of modified Krebs' solution and continuously oxygenated. After a $1 \mathrm{~h}$ equilibration period, samples were collected before and after LPS stimulation (10 $\mu \mathrm{g} / \mathrm{ml}$ for $8 \mathrm{~min}$ ) for assessing basal and LPS-evoked release of ATP respectively. The ecto-ATPase inhibitor ARL $67156(100 \mu \mathrm{M}$; Sigma) was added to the Krebs' solution to prevent the breakdown of released ATP. ATP standards $\left(100 \mu \mathrm{l}\right.$ of $5 \times 10^{-10} \mathrm{M}$ to $\left.1 \times 10^{-6} \mathrm{M}\right)$ and $100 \mu \mathrm{l}$ of unknown samples were run in triplicate using a microplate luminometer (Veritas microplate luminometer, Turner Biosystems) using the CellTiter-Glo Luminescent Cell Viability Assay (G7570; Promega) according to the manufacturers' instructions, similar to previously described (Yip et al., 2009). Data are expressed as percentage of ATP content in the basal fractions.

\section{LPS-induced mechanical hyperalgesia and behavioral testing}

Acute activation of spinal microglia was achieved by the intrathecal injection of LPS as previously described (Clark et al., 2006, 2009). Under isoflurane anesthesia, LPS was intrathecally injected twice into the lumbar region (between the L5 and L6 vertebrae) of the spine using a 26 G 3/8 inch needle connected to a $25 \mu \mathrm{l}$ Hamilton syringe. Rats received $2 \mu \mathrm{g}$ intrathecal dose of LPS (dissolved in $10 \mu \mathrm{l}$ of $0.9 \%$ saline) to prime the immune system. Twenty-four hours later, a second intrathecal injection was administered consisting of one of the following: $2 \mu \mathrm{g}$ of LPS, vehicle ( $0.9 \%$ saline), inhibitor alone [either $50 \mu$ g oxidized ATP (Sigma) or $50 \mu$ g of A-438079 (Tocris Bioscience)] or $2 \mu \mathrm{g}$ of LPS plus inhibitor. In separate experiments, P2X7 wild-type and knock-out mice received $2 \mu \mathrm{g}$ of intrathecal LPS (dissolved in $5 \mu \mathrm{l}$ of $0.9 \%$ saline) followed by a second LPS dose $24 \mathrm{~h}$ later.

Mechanical sensitivity in rats was assessed by measuring paw withdrawal threshold (PWT) to increasing mechanical force applied to the 
A

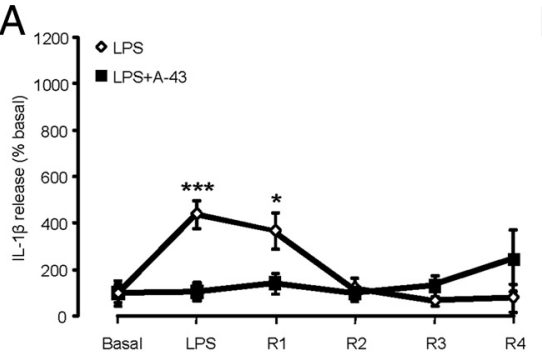

$\mathrm{B}_{350}$

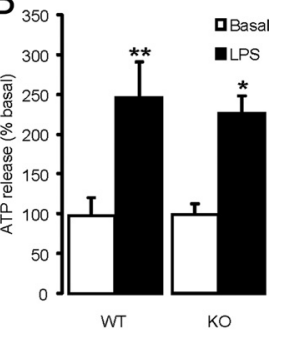

C
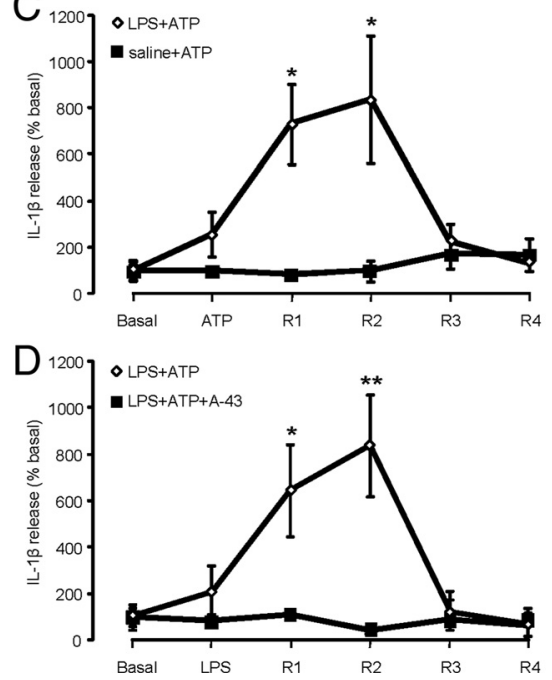

Figure 1. Disruption of P2X7 receptor signaling attenuates both LPS- and ATP-evoked IL-1 $\beta$ release in rat dorsal horn slices, but does not alter ATP release. $A$, LPS superfusion $(10 \mu \mathrm{g} / \mathrm{ml}$ for $8 \mathrm{~min}$ ) induces rapid release of IL- $1 \beta$ from the rat dorsal horn ( $n=6$ slices). Superfusion of the specific P2X7 receptor antagonist A-438079 (A-43) before and during LPS application (16 min in total) inhibits LPS-evoked IL- $\beta$ release $(n=6$ slices). Basal release: LPS $=11.7 \pm 4.6 \mathrm{pg} / 8 \mathrm{ml}$ fraction, $\mathrm{LPS}+\mathrm{A}-43=13.8 \pm 5.6 \mathrm{pg} / 8 \mathrm{ml}$ fraction. $B$, LPS incubation $(10 \mu \mathrm{g} / \mathrm{ml}$ for $8 \mathrm{~min})$ induces release of ATP from P2X7 wild-type $(n=5)$ and knock-out $(n=4)$ dorsal horn slices. Basal release: wild-type $=4.44 \pm 0.9 \mathrm{fmol}$ per $100 \mu \mathrm{l}$, knock-out $=2.6 \pm 0.4 \mathrm{fmol}$ per 100 $\mu$ l. C, ATP superfusion (1 mm for $8 \mathrm{~min}$ ) induces significant but delayed release of IL-1 $\beta 24 \mathrm{~h}$ following an intrathecal LPS priming dose ( $n=5$ slices). However, in the absence LPS priming, ATP superfusion does not induce significant release of IL- $1 \beta(n=5$ slices). Basal release: LPS + ATP $=4.5 \pm 1.2 \mathrm{pg} / 8 \mathrm{ml}$ fraction and saline + ATP $=3.4 \pm 1.3 \mathrm{pg} / 8 \mathrm{ml}$ fraction. $D$, ATP superfusion (1 $\mathrm{mm}$ for $8 \mathrm{~min}$ ), following LPS priming, induces significant but delayed release of IL-1 $\beta$ from the rat dorsal horn ( $n=5$ slices). Superfusion of the specific $P 2 X 7$ receptor antagonist A-43 before and during ATP application (16 min in total) inhibits ATP-evoked IL-1 $\beta$ release ( $n=6$ slices). Basal release: ATP $=2.6 \pm 1.4 \mathrm{pg} / 8 \mathrm{ml}$ fraction, ATP $+\mathrm{A}-43=6.9 \pm$ $2.3 \mathrm{pg} / 8 \mathrm{ml}$ fraction. ${ }^{*} p<0.05,{ }^{* *} p<0.01,{ }^{* * *} p<0.001$, one-way ANOVA, post hoc Tukey's test.

dorsal surface of the rat hindpaw using an Analgesymeter (Ugo-Basile). Mechanical withdrawal thresholds in mice were assessed using calibrated von Frey hairs (Touch Test, Stoelting) according to the "up-down" method (Chaplan et al., 1994). Adult mice of both sexes were acclimatized to individual housing 1 week before testing. Three baseline readings were taken before treatment and on each testing occasion animals were acclimatized to the behavioral equipment (Perspex cubicles atop a wire mesh grid) for up to $1 \mathrm{~h}$ before the start of testing. Responses of P2X7 knock-out mice were compared to their wild-type littermates. The experimenter was blinded to genotype. Nylon filaments were applied to the plantar surface of the hindpaw until they bent and were then held in position for $3 \mathrm{~s}$. A positive response was defined as withdrawal of the paw not associated with locomotion or grooming. Each test started with application of the $0.6 \mathrm{~g}$ filament, and each hindpaw was assessed alternately. If a positive response was observed, the next lower force hair was applied and vice versa until a change in response was observed. Four subsequent hairs were then assessed using the up/down sequence. The 50\% paw withdrawal threshold was calculated using the method described by
A
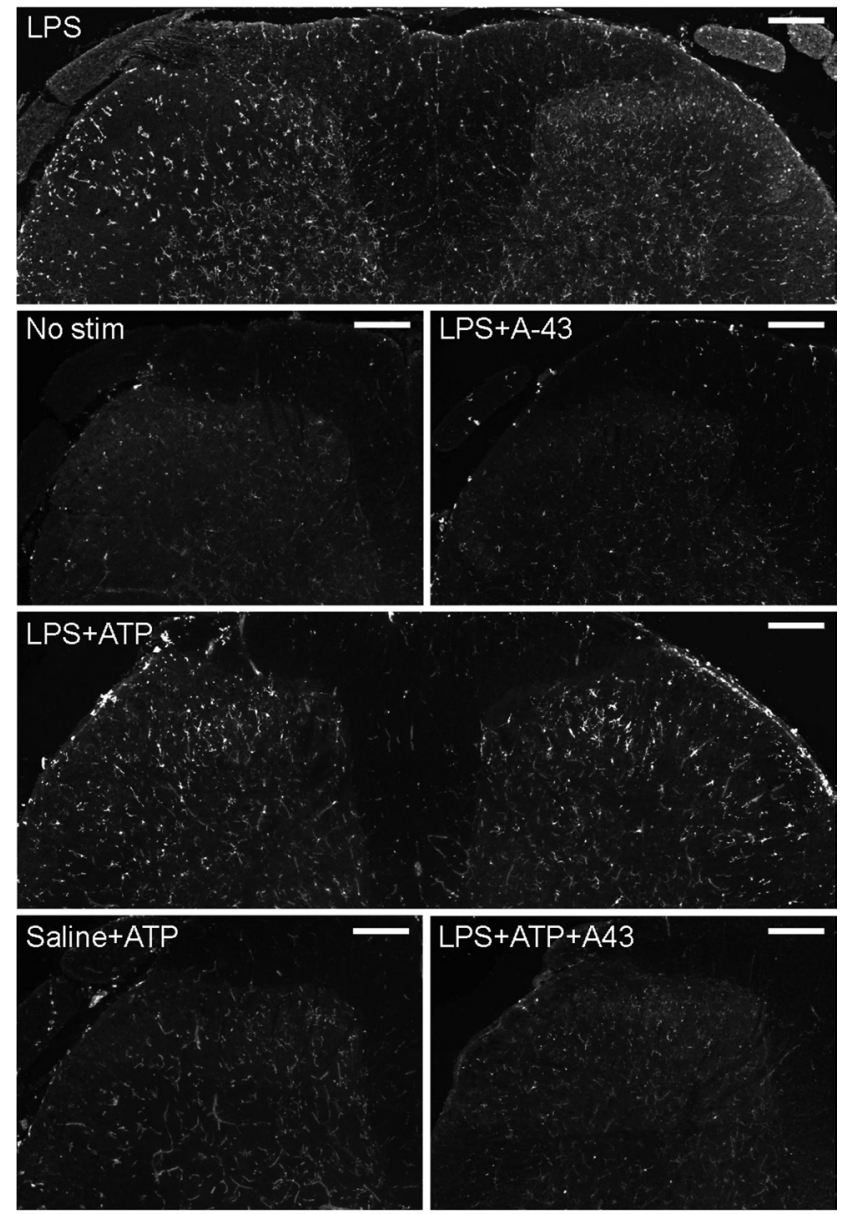

$\mathrm{B}$

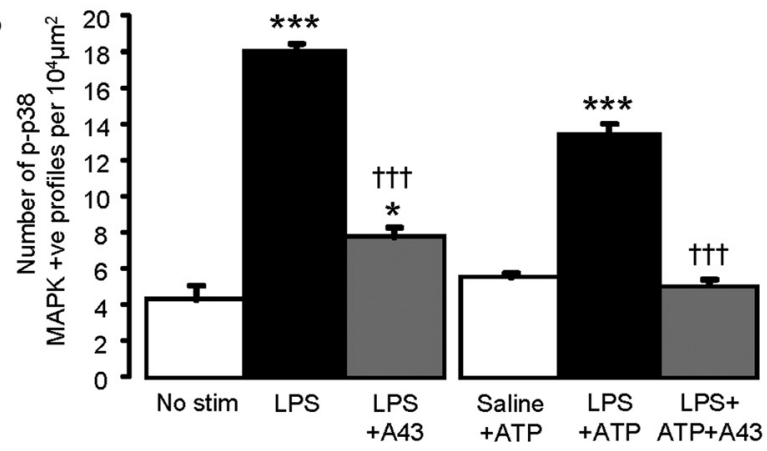

Figure 2. Disruption of P2X7 receptor signaling attenuates both LPS- and ATP-induced p-p38 MAPK phosphorylation in rat dorsal horn slices. $A$, LPS superfusion results in an increase in $\mathrm{p} 38 \mathrm{MAPK}$ phosphorylation in rat SC slices compared to unstimulated slices, and is prevented by superfusion of the P2X7 antagonist A-438079 (A-43). In addition, following LPS priming ATP superfusion results in an increase in $\mathrm{P} 38 \mathrm{MAPK}$ phosphorylation in rat $\mathrm{SC}$ slices compared to ATP alone, and is prevented by A-43 superfusion. Scale bars, $100 \mu \mathrm{m}$. $\boldsymbol{B}$, Quantification of p-p38 immunoreactivity in rat SC slices $\left(n=4-8\right.$ slices per group). ${ }^{*} p<0.05,{ }^{* * *} p<0.001$ compared to unstimulated slices, ${ }^{+t \dagger} p<0.001$ compared to LPS and LPS + ATP slices, oneway ANOVA, post hoc Tukey's test.

Dixon (1980). Mechanical sensitivity readings were taken before LPS injection and then at set intervals after injection.

\section{Phospho-p38 mitogen-activated protein kinase}

\section{immunohistochemistry in the dorsal horn}

At completion of the release experiments, the dorsal horn slices were fixed in $4 \%$ paraformaldehyde (overnight at $4^{\circ} \mathrm{C}$ ). At the completion of behavioral experiments, animals were under pentobarbital anesthesia, transcardially perfused with $0.9 \%$ saline solution followed by $4 \%$ para- 
formaldehyde in $0.1 \mathrm{~m}$ phosphate buffer. The lumbar spinal cord was excised, postfixed for $4 \mathrm{~h}$ in the perfusion fixative. All tissues were then cryoprotected in $20 \%$ sucrose in $0.1 \mathrm{M}$ phosphate buffer $\left(72 \mathrm{~h}\right.$ at $\left.4^{\circ} \mathrm{C}\right)$ and frozen in O.C.T. embedding compound (VWR). Transverse sections $(20 \mu \mathrm{m})$ were cryostat cut and thaw mounted onto glass slides. Slides were incubated overnight with primary antibody solution for phosphorylated p38 mitogen-activated protein kinase (rabbit anti-p-p38 MAPK, p-p38, 1:100, Cell Signaling Technology) followed by secondary antibody solution (goat anti-rabbit IgG-conjugated Alexa Fluor 488, 1:1000, Invitrogen). To determine the cellular distribution of p-p38, sections were counterstained with primary antibodies against markers for neurons (mouse anti-neuronal nuclei, NeuN, 1:500, Millipore Bioscience Research Reagents), astrocytes (mouse anti-glial fibrillary acidic protein, GFAP, 1:1000, Abcam), and oligodendrocytes (mouse anti-adenomatous polyposis coli, APC, 1:500, Oncogene Research Products). For counterstaining of the microglial cell population p-p38 staining was visualized with ExtrAvidin-FITC (1:500, Sigma) following signal amplification with $\mathrm{ABC}$ (Vector Laboratories) and biotinyl tyramide (NEN Life Science Products). Sections were then incubated with primary antibody for a microglial-specific protein, Iba-1 (rabbit anti-ionized calciumbinding adapter molecule 1, 1:1000, Wako Chemicals) followed by secondary antibody solution (goat anti-rabbit IgG-conjugated Alexa Fluor 546, 1:1000, Invitrogen). Slides were coverslipped with Vectashield mounting medium (Vector Laboratories) and visualized under a Zeiss Axioplan 2 fluorescent microscope with Apotome.

\section{Quantification and statistics}

Following release experiments quantitative assessment of p-p38 immunostaining was performed by counting the number of positive profiles within a fixed area of the dorsal horn. As previously described (Clark et al., 2007a,b, 2009), a box measuring $10^{4} \mu \mathrm{m}^{2}$ was placed onto areas of the lateral, central, and medial dorsal horn, and the number of profiles positive for p-p38 was counted within this area. Alternatively, following behavioral experiments, the number of $\mathrm{p}$-p38-positive cells within the whole dorsal horn $\left(\sim 70^{4} \mu \mathrm{m}^{2}\right)$ was determined. These measurement protocols were performed on three L5 spinal sections (determined by anatomic identification) from each animal, with a minimum of three animals examined per group. Data are presented as mean \pm SEM.

For immunohistochemical and release studies, one-way repeated measures of ANOVA followed by Tukey's post hoc test was used. For the analysis of behavioral data, two-way repeated measures of ANOVA followed by Tukey's post hoc test was used. $p<0.05$ was set as the level of statistical significance.

\section{Results}

LPS- and ATP-induced IL-1 $\beta$ release from spinal microglia in the isolated dorsal horn are $\mathrm{P} 2 \mathrm{X} 7$ dependent

The purinergic $\mathrm{P} 2 \mathrm{X} 4$ and $\mathrm{P} 2 \mathrm{X} 7$ receptors have been localized to microglia (Collo et al., 1997; Tsuda et al., 2003), and activation of the P2X7 receptor by high concentrations of ATP has been proposed to be critical for IL- $1 \beta$ processing and release in microglial cell lines primed with LPS (Ferrari et al., 2006). Here we investigated the role of the $\mathrm{P} 2 \mathrm{X} 7$ receptor in IL- $1 \beta$ release in an ex vivo isolated dorsal horn preparation in which a brief application of
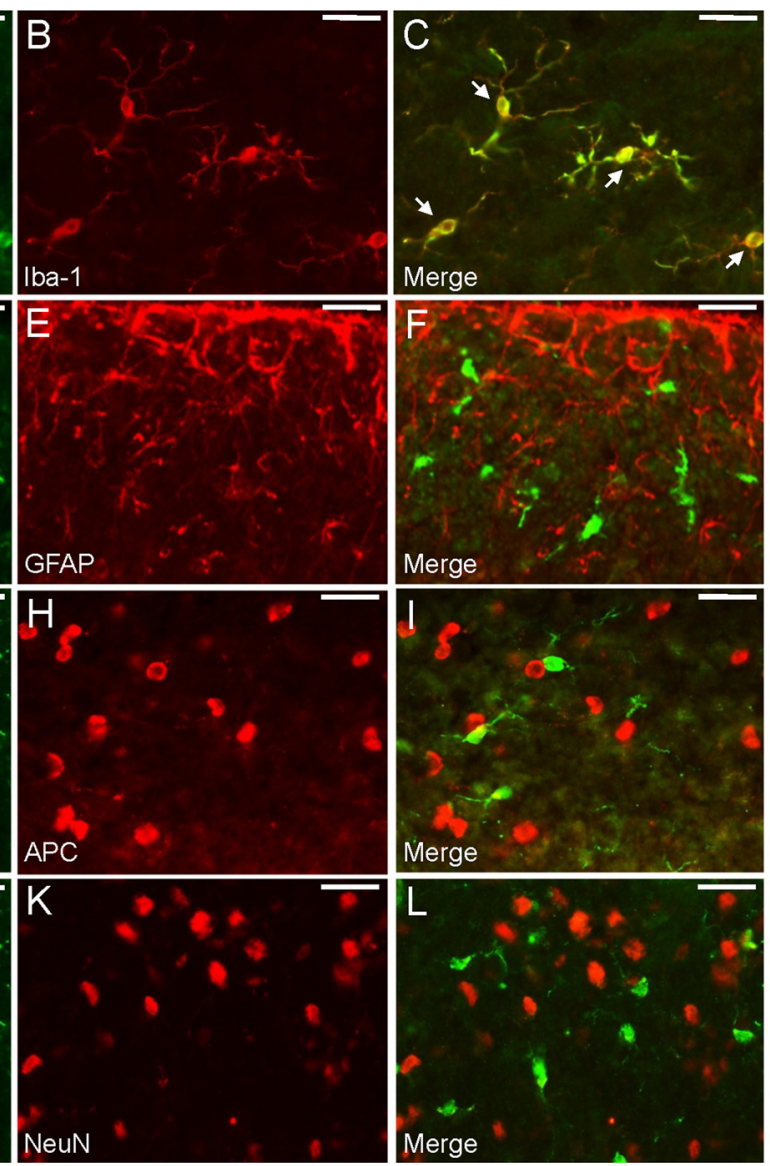

Figure 3. LPS induces p38 MAPK phosphorylation in spinal microglia. $\boldsymbol{A}-\boldsymbol{C}, \mathrm{p}-\mathrm{p} 38$ (green, $\boldsymbol{A}$ ) colocalizes with lba-1 (red, $\boldsymbol{B})$, a calize with GFAP (red, $\boldsymbol{E}$; merge, $\boldsymbol{F}$ ). G-I, p-p38 (green, $\boldsymbol{G}$ ) does not colocalize with APC (red, $\boldsymbol{H}$; merge, $\boldsymbol{I}$ ). J- $\boldsymbol{L}, \mathrm{p}$-p38 (green, $\boldsymbol{J})$ does not colocalize with NeuN (red, $\boldsymbol{K}$; merge, $\boldsymbol{L}$ ). Scale bars, $25 \mu \mathrm{m}$.

LPS induces rapid release of IL-1 $\beta$ and caspase-1 (Clark et al., 2006) with no need for exogenous ATP as a second stimulus.

As we previously observed in the superfusates collected from isolated dorsal horn preparations the levels of IL- $1 \beta$ under basal conditions ranged from 1 to $10 \mathrm{pg}$, which are values just above the sensitivity of the ELISA, indicating that this cytokine is unlikely to be secreted in the spinal cord under normal conditions and suggesting that any basal release may be the result of preparation of the dorsal horn slice. However, following a brief ( $8 \mathrm{~min}$ ) application of LPS, the contents of IL- $1 \beta$ in the superfusates were significantly increased to $440 \pm 59 \%$ above basal IL-1 $\beta$ levels (Fig. $1 A$ ). This increase was still significant in the first recovery fraction (R1) following stimulation, returning to basal levels in the second and third recovery fractions (R2 and R3). The presence of the specific P2X7 antagonist A-438079 (A-43) in the superfusing buffer prevented LPS-induced release of IL- $1 \beta$ (Fig. $1 A$ ), suggesting that LPS induces the release of ATP, which in turn modulates the release of IL- $1 \beta$ via $\mathrm{P} 2 \mathrm{X} 7$ receptor activation.

Indeed, when we examined the content of ATP in superfusate samples from spinal cord slices, we observed a significant increase in ATP levels following incubation of spinal cord slices with LPS. In slices taken from $P 2 X 7$ wild-type mice, LPS resulted in an increase in ATP content to $245 \pm 45 \%$ above basal ATP levels (Fig. $1 B$ ). Similarly, in spinal cord slices from P2X7 knock-out mice, LPS resulted in an increase of $228 \pm 20 \%$ above basal ATP levels (Fig. $1 B$ ). These data suggest that LPS induces a rapid re- 

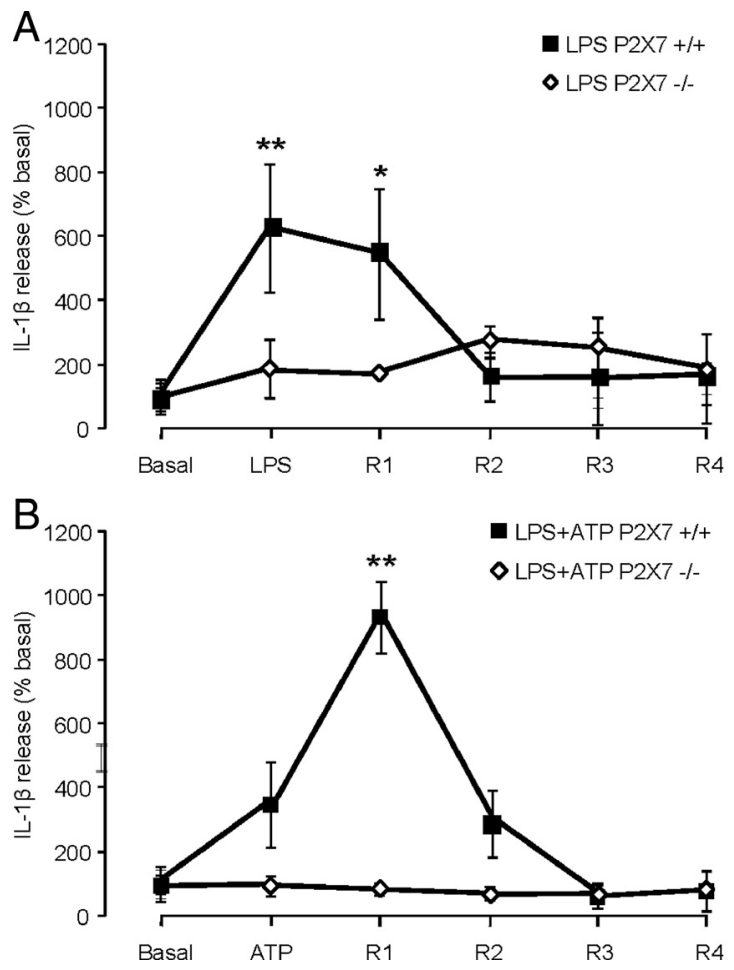

Figure 4. LPS and ATP-evoked IL-1 $\beta$ release is abolished in P2X7-null mice. $A$, In SC slices from wild-type $(\mathrm{P} 2 \mathrm{X} 7+/+)$ mice release of IL-1 $\beta$ from the dorsal horn is significantly increased following LPS superfusion ( $10 \mu \mathrm{g} / \mathrm{ml}$ for $8 \mathrm{~min} ; n=6$ slices). In contrast, in SC slices from P2X7 knock-out mice (P2X7-/-), LPS superfusion does not induce significant IL-1 $\beta$ release $(n=6$ slices). Basal release $=10.9 \pm 6.6 \mathrm{pg} / 8 \mathrm{ml}$ fraction $(P 2 X 7+/+)$ and $6.6 \pm 1.8$ $\mathrm{pg} / 8 \mathrm{ml}$ fraction (P2X7-/-).B, In wild-type SC slices release of IL- $1 \beta$ is significantly increased by ATP superfusion ( $1 \mathrm{~mm}$ for $8 \mathrm{~min}, 24 \mathrm{~h}$ following intrathecal LPS; $n=5$ slices). In contrast, following LPS priming in SC slices from P2X7 knock-out mice, ATP superfusion does not induce significant IL-1 $\beta$ release $(n=5$ slices). Basal release $=6.1 \pm 2.4 \mathrm{pg} / 8 \mathrm{ml}$ fraction $(\mathrm{P} 2 \mathrm{X} 7+/+)$ and $3.0 \pm 0.7 \mathrm{pg} / 8 \mathrm{ml}$ fraction (P2X7-/-). ${ }^{*} p<0.05,{ }^{* *} p<0.01$, one-way ANOVA, Tukey post hoc.

lease of ATP in the dorsal horn, which is unaltered by the absence of the $\mathrm{P} 2 \mathrm{X} 7$ receptor.

However, when we examined whether application of ATP ( $1 \mathrm{~mm}$ ) alone resulted in release of IL- $1 \beta$ in the dorsal horn, we failed to determine an increase of this cytokine levels over basal (data not shown). We postulated that in order for ATP to release IL- $1 \beta$ from microglial cells in the dorsal horn, these should be first primed with LPS, as is required in microglial cell culture systems (Ferrari et al., 2006). Therefore, we administered an intrathecal dose of LPS ( $2 \mu \mathrm{g} / \mathrm{rat}) 24 \mathrm{~h}$ before the release experiments to prime the immune system. We observed that in LPSprimed dorsal horn slices, ATP ( $1 \mathrm{~mm}$ ) evoked significant IL-1 $\beta$ release (Fig. 1C) starting as soon as $8 \mathrm{~min}$ after superfusion, with IL- $1 \beta$ levels significantly increased in both the first and second recovery fractions (R1 and R2), peaking at $837 \pm 275 \%$ of basal IL- $1 \beta$ levels. ATP did not induce release of IL- $1 \beta$ from the dorsal horn of rats that had received saline injection instead of LPS (Fig. $1 C)$, suggesting that ATP alone is insufficient to release IL-1 $\beta$ from the isolated spinal cord, requiring an initial priming stimulus in order for release to occur. As the mean basal IL- $1 \beta$ levels from LPS-primed and saline-treated spinal cord slices were comparable $(4.5 \pm 1.2 \mathrm{pg} / 8 \mathrm{ml}$ fraction and $3.4 \pm 1.3 \mathrm{pg} / 8 \mathrm{ml}$ fraction, respectively), we conclude that the intrathecal injection of $2 \mu \mathrm{g}$ of LPS does not alter basal IL- $1 \beta$ secretion. The release of IL- $1 \beta$ induced by ATP in LPS-primed dorsal horn was prevented by the
A
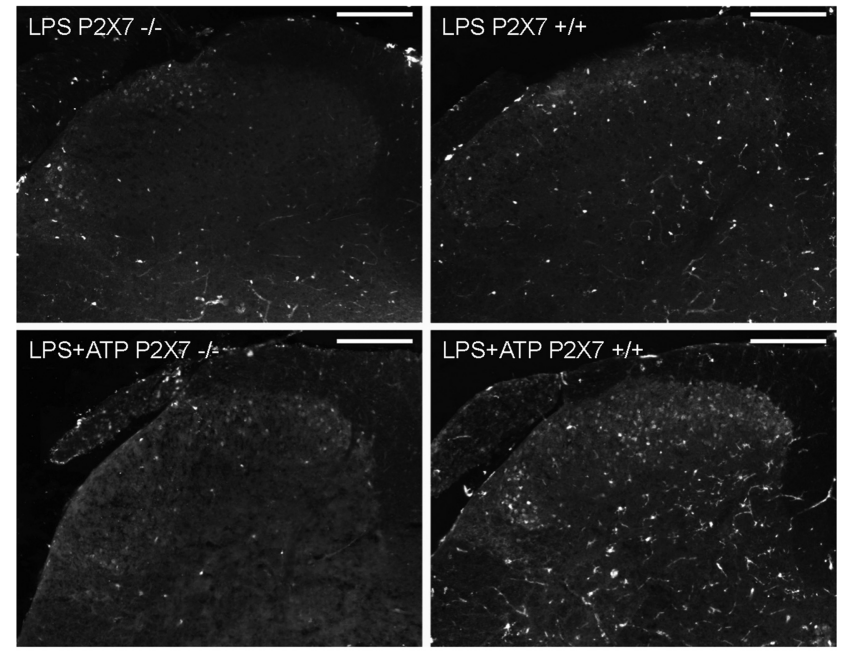

B

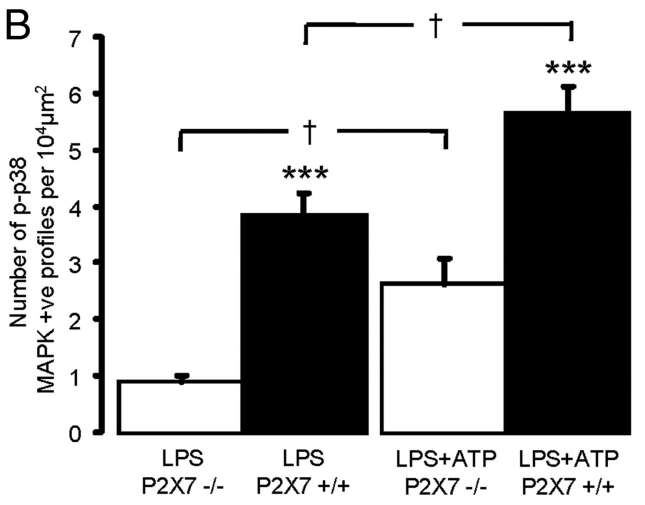

Figure 5. Disruption of P2X7 receptor signaling attenuates both LPS- and ATP-induced p-p38 MAPK phosphorylation in mouse dorsal horn slices. $\boldsymbol{A}$, LPS superfusion results in an increase in P38 MAPK phosphorylation in SC slices from wild-type mice, which is absent in SC slices from P2X7 knock-out mice. Similarly, following LPS priming, ATP superfusion results in an increase in p38 MAPK phosphorylation in SC slices from wild-type mice, which is attenuated in P2X7 receptor knock-out mice. Scale bars, $100 \mu \mathrm{m}$. B, Quantification of p-p38 immunoreactivity in mouse SC slices ( $n=5-6$ slices per group). ${ }^{* *} p<0.001$ knock-out versus wild-type, ${ }^{+} p<0.05$ compared to indicated group, one-way ANOVA, post hoc Tukey's test.

presence of A-438079 (Fig. 1D), supporting the evidence that ATP determines the release of this cytokine through the activation of $\mathrm{P} 2 \mathrm{X} 7$ receptors.

Both TLR4 for LPS and P2X7 receptors for ATP are expressed by microglial cells (Collo et al., 1997; Lehnardt et al., 2002), suggesting that these cells are the likely source of IL- $1 \beta$ in these experiments. Indeed, in the same dorsal horn slices used for measuring IL- $1 \beta$ release, we confirmed that LPS induced significant phosphorylation of p38 MAPK compared to unstimulated slices (Fig. 2A,B). Measurable background p-p38 staining was found in unstimulated slices, indicating that the slicing procedure itself resulted in phosphorylation of this stress-activated protein kinase; however, p-p38 was detected at very low levels under these conditions and can therefore be considered as a marker for rapid microglial activation following LPS (Clark et al., 2006, 2009), as well as other inflammatory stimuli. Furthermore, the presence of A-438079 significantly attenuated LPS-induced p-p38 MAPK (Fig. $2 A, B$ ). In accordance with the release data, ATP induced a significant increase in the number of p-p38-positive microglial cells in LPS-primed slices (Fig. 2A,B), and the presence of A-438079 prevented ATP-induced increases in p-p38 (Fig. $2 A, B)$. To identify the cell types in which phosphorylation of $\mathrm{p} 38$ 
had occurred, we examined the cellular distribution of p-p38 immunoreactivity in spinal cord slices. Immunoreactivity for $\mathrm{p}$ p38 was found to colocalize with Iba-1, a marker for microglial cells (Fig. $3 A-C$ ). Double staining indicated that p-p38 immunoreactivity showed no colocalization with markers for astrocytic (GFAP), oligodendrocytic (APC), or neuronal $(\mathrm{NeuN})$ cell populations (Fig. 3D-L), suggesting that this increased phosphorylation had occurred following the activation of spinal microglia by LPS and ATP.

Together these data suggest that the $\mathrm{P} 2 \mathrm{X} 7$ receptor is essential for both LPSand ATP-induced IL- $1 \beta$ release and p38 MAPK phosphorylation in dorsal horn microglia. Similarly to IL- $1 \beta$ release in microglial cell lines, ATP is able to induce the release of this cytokine in the dorsal horn and enhanced p38 MAPK phosphorylation, only following LPS priming of spinal microglia. In contrast to cell lines, LPS-induced release of this cytokine in the dorsal horn does not require exogenous ATP as a second stimulus because LPS increases extracellular endogenous ATP levels.

\section{LPS- and ATP-evoked release of IL-1 $\beta$} are absent in $P 2 X 7$ knock-out mice To further validate the role of $\mathrm{P} 2 \mathrm{X} 7$ receptor activation in the modulation of IL- $1 \beta$ release, we used dorsal horn slices from $P 2 X 7$ knock-out and wild-type mice. Mean basal IL-1 $\beta$ levels from wild-type and knock-out mice were comparable $(10.9 \pm 6.5 \mathrm{pg} / 8 \mathrm{ml}$ fraction and $6.5 \pm 1.8$ $\mathrm{pg} / 8 \mathrm{ml}$ fraction respectively), suggesting that the P2X7 receptor does not tonically modulate basal release of this cytokine. In slices from wild-type mice, LPS superfusion for $8 \mathrm{~min}$ induced rapid release of IL- $1 \beta$ to $627 \pm 201 \%$ of basal IL- $1 \beta$ levels (Fig. $4 A$ ) in a manner similar to that observed from rat dorsal horn slices. This increase was still significant in the first 8 min recovery fraction (R1) after LPS challenge, returning to basal levels in the second and third $8 \mathrm{~min}$ recovery fractions (R2 and R3). However, in slices from $P 2 X 7$ knock-out mice, LPS application for $8 \mathrm{~min}$ failed to evoke IL-1 $\beta$ release either during application or in the recovery fractions (Fig. $4 A$ ).

Similarly, in dorsal horn slices from wild-type mice primed with intrathecal LPS, ATP ( $1 \mathrm{~mm}$ ) superfused for 8 min induced significant release of IL- $1 \beta$ in the collected superfusates (Fig. $4 B$ ). This increase peaked during the first recovery fraction (R1), reaching $931 \pm 112 \%$ of basal IL- $1 \beta$ levels. In contrast, in slices from P2X7 knock-out mice primed with LPS, ATP application failed to evoke significant changes in IL- $1 \beta$ superfusate contents (Fig. 4B).

Following LPS challenge, immunoreactivity for p-p38 MAPK was significantly higher in dorsal horns from $P 2 X 7$ wild-type
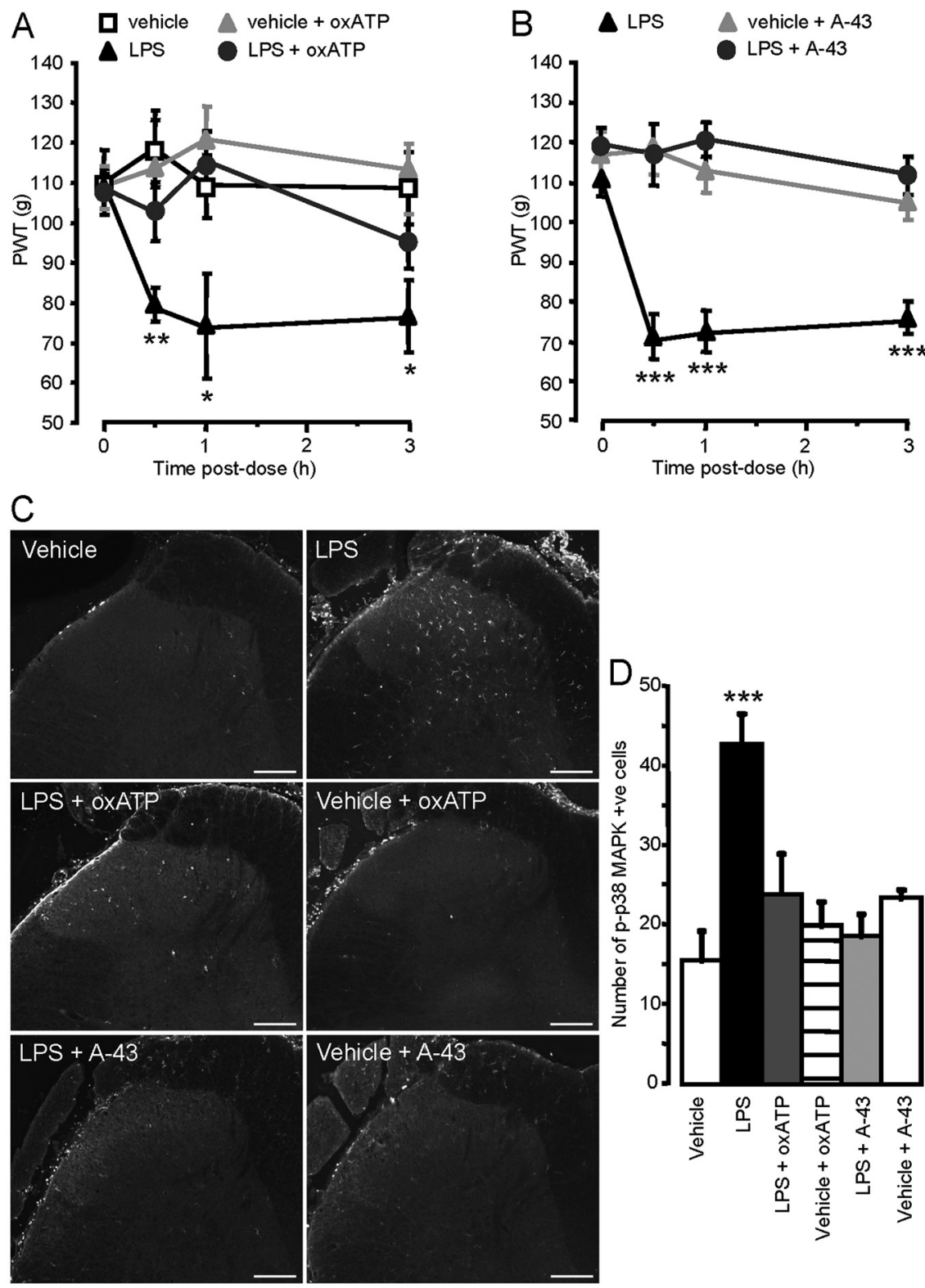

Figure 6. LPS-induced mechanical hyperalgesia and phosphorylation of p 38 MAPK are prevented by P2X7 receptor inhibition. $A, B$, Intrathecal LPS produces significant mechanical hyperalgesia. Concomitant intrathecal injection of oxATP $(A)$ or A-438079 $(A-43)(B)$ prevented LPS-induced mechanical hyperalgesia ( $n=8$ rats per group). Each data point represents the mean \pm SEM Scale bars, $100 \mu \mathrm{m}$. D, Quantification of p-p38-positive cells in the spinal dorsal horn ( $n=3-8$ per group). ${ }^{*} p<0.05,{ }^{* *} p<0.01$, ${ }^{* * *} p<0.001$ compared to vehicle-treated animals, two-way RM ANOVA $(\boldsymbol{A}, \boldsymbol{B})$, one-way ANOVA $(\boldsymbol{D})$, post hoc Tukey's test.

than from $P 2 X 7$ knock-out mice (Fig. $5 A, B$ ), while the numbers of microglial cells (cells positive for Iba-1) in wild-type and knock-out mice were comparable $\left(5.8 \pm 0.2\right.$ cells per $10^{4} \mu \mathrm{m}^{2}$ and $6.1 \pm 0.3$ cells per $10^{4} \mu \mathrm{m}^{2}$, respectively), suggesting that while overall microglial cell numbers remain unchanged in $P 2 X 7$ knock-out mice, activation of these cells following LPS superfusion is attenuated. Similarly, following ATP superfusion through wild-type LPS-primed dorsal horn slices p-p38 MAPK immunoreactivity was significantly higher than in slices from $P 2 X 7$ knockout mice, and wild-type slices challenged with LPS only (Fig. $5 A, B$ ).

These data suggest that $\mathrm{P} 2 \mathrm{X} 7$ receptor activation is essential for both LPS- and ATP-induced IL- $1 \beta$ release and $\mathrm{p} 38$ phosphorylation in the isolated dorsal horn. However, p38 MAPK activation which is downstream of both TLR4 and P2X7, occurs 


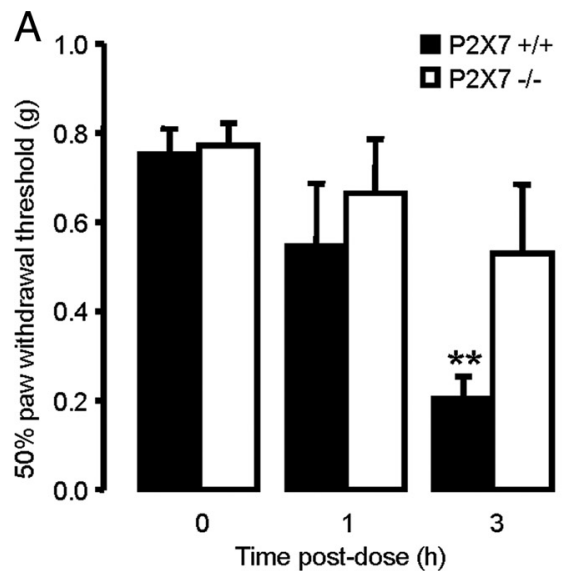

C
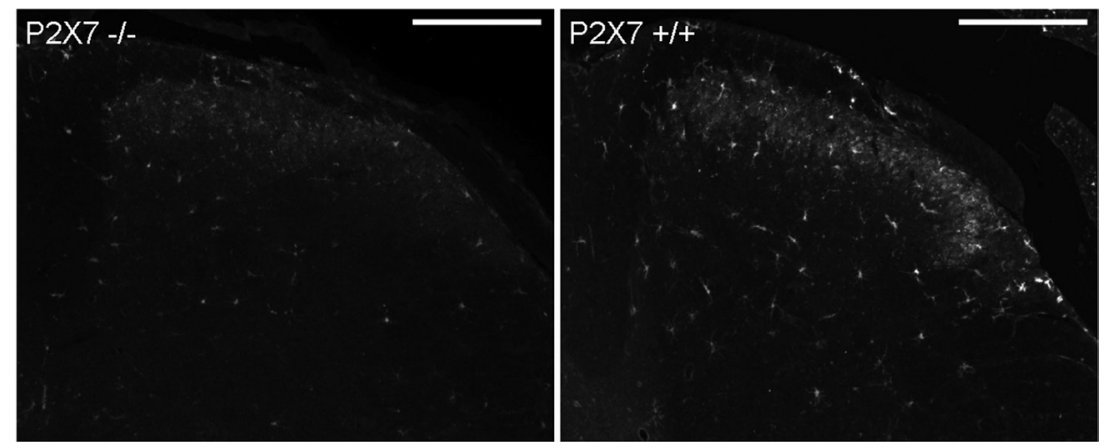

Figure 7. LPS-induced mechanical hypersensitivity and $\mathrm{p} 38$ MAPK phosphorylation is absent in P2X7 knock-out mice. $A$, Intrathecal LPS produces significant mechanical allodynia in wild-type $(P 2 X 7+/+)$ mice (black bars, $n=10)$, but fails to induce changes in mechanical threshold in P2X7 knock-out (P2X7-/-) mice (white bars, $n=12) .{ }^{* *} p<0.01$ compared to postdose thresholds, two-way RM ANOVA, post hoc Tukey's test. $B$, Quantification of p-p38-positive cells in the spinal dorsal horn $(n=4$ per group). C, Intrathecal LPS results in an increase in 338 MAPK phosphorylation in wild-type, but not P2X7 knock-out mice. Scale bars, $100 \mu \mathrm{m}$.

following LPS challenge independently from P2X7 receptors whose activation increases the extent of $\mathrm{p} 38$ phosphorylation induced by LPS.

\section{Intrathecal LPS-induced mechanical hypersensitivity is P2X7 dependent}

We have recently shown that the intrathecal administration of two small doses of LPS ( $2 \mu \mathrm{g} / \mathrm{rat})$ within $24 \mathrm{~h}$ induces mechanical hyperalgesia following the second administration, but not the first priming dose (Clark et al., 2006, 2009), via spinal microglial activation and release of IL-1 $\beta$ (Clark et al., 2006). Such acute activation of spinal microglia has relevance to neuropathic pain mechanisms associated with microglial activation due to the observation that TLR4-null mice develop less severe neuropathic hypersensitivity than wild-type mice (Tanga et al., 2005). Here we examined the potential contribution of $\mathrm{P} 2 \mathrm{X} 7$ receptor activation to intrathecal LPS-induced mechanical hyperalgesia.

Mechanical hypersensitivity developed from $30 \mathrm{~min}$ to $3 \mathrm{~h}$ following the injection of the second LPS dose (Fig. 6A, B). The concomitant intrathecal administration of the nonspecific $\mathrm{P} 2 \mathrm{X} 7$ antagonist oxidized ATP (oxATP) (Fig. 5A) or the specific P2X7 antagonist A-438079 (A-43) (Fig. 6B) prevented the development of LPS-induced mechanical hyperalgesia. Neither oxATP nor A-438079 had any effect on normal paw withdrawal thresholds (Fig. 6A,B). Thus, these behavioral data suggest that intrathecal LPS-induced hyperalgesia requires the mediation of ATP via activation of $\mathrm{P} 2 \mathrm{X} 7$ receptor.
In the dorsal horn of the spinal cord obtained from the rats after the behavioral studies, the number of cells positive for p-p38 MAPK immunoreactivity was higher in LPS-treated than in vehicle-treated animals (Fig. 6C,D). Furthermore, both oxATP and A-438079 prevented LPS-induced phosphorylation of p38 MAPK in these cells, which were morphologically identified as microglia (Fig. 6C,D).

Finally, we examined the role played by $\mathrm{P} 2 \mathrm{X} 7$ receptor in the mediation of mechanical hypersensitivity and p38 MAPK phosphorylation following intrathecal LPS in $\mathrm{P} 2 \mathrm{X} 7$ wild-type and knock-out mice. Intrathecal LPS on day 1 ( $2 \mu \mathrm{g} /$ mouse) did not alter PWT to either noxious or non-noxious mechanical stimuli in wildtype or knock-out mice (data not shown). In wild-type mice a second intrathecal injection of LPS ( $2 \mu \mathrm{g} /$ mouse) on day 2 produced a significant reduction in mechanical withdrawal thresholds $3 \mathrm{~h}$ following administration (Fig. 7A), while in $P 2 X 7$ knock-out mice the second LPS administration produced no alteration in mechanical thresholds up to $3 \mathrm{~h}$ after injection (Fig. 7A). Immunostaining of the dorsal horn after the behavioral testing revealed that both wild-type and $P 2 X 7$ knock-out mice exhibited significantly higher p-p38 immunoreactivity following the second intrathecal LPS administration compared to wild-type mice receiving the LPS priming dose followed by intrathecal saline $24 \mathrm{~h}$ later (Fig. 7B). However, in wild-type mice the number of cells positive for p-p38 immunoreactivity were significantly higher than in $P 2 X 7$ knock-out mice (Fig. $7 B, C$ ), suggesting that both LPS-induced mechanical hypersensitivity and $\mathrm{p} 38$ phosphorylation are at least in part dependent on P2X7 receptor signaling.

Together these data indicate the involvement of spinal P2X7 receptor activation in the nociceptive hypersensitivity associated with intrathecal injection of LPS.

\section{Discussion}

In this study, we show that brief application of LPS to the dorsal horn of the spinal cord induces release of IL-1 $\beta$ and phosphorylation of p38 MAPK in microglial cells through $\mathrm{P} 2 \mathrm{X} 7$ receptormediated mechanisms. As LPS also induces release of ATP, we suggest that increased levels of extracellular endogenous ATP are ultimately responsible for the release of this cytokine. However, as the application of exogenous ATP does not induce release of IL- $1 \beta$ unless the spinal cord is primed with LPS $24 \mathrm{~h}$ before ATP challenge, our data support the idea that intrathecal LPS induces the synthesis of IL- $1 \beta$ and caspase- 1 maturation, which are both required for P2X7-mediated release of mature IL- $1 \beta$ from dorsal horn microglia.

Both the secretion and maturation of IL- $1 \beta$ are tightly regulated processes (Burns et al., 2003; Ferrari et al., 2006). Vesicular secretion of mature IL- $1 \beta$ consists of several concomitant pathways, including phospholipase A2-mediated release of lysosomal IL-1 $\beta$ (Rubartelli et al., 1990; Andrei et al., 1999, 2004) and the 
shedding of microvesicles from the plasma membrane (MacKenzie et al., 2001). In both pathways, secretion of mature IL-1 $\beta$ is achieved via the inflammasome, a caspase-activating complex (Martinon et al., 2002). LPS is able to stimulate rapid release of the inflammatory caspases- 1 and -5 in the supernatants of THP-1 cells (Martinon et al., 2002). Concomitant release of accessory proteins has been proposed as a mechanism for extracellular caspase activation (Martinon et al., 2002; Martinon and Tschopp, 2004). In particular, ASC has been observed to associate with active caspase- 1 in THP-1 cell supernatants (Martinon et al., 2002), and is required for the activation of caspase-1 (Mariathasan et al., 2004; Yamamoto et al., 2004) and LPS-induced IL-1 $\beta$ maturation (Martinon et al., 2002). Importantly, the inflammasome also appears to play a key role in the regulation of IL- $1 \beta$ secretion in the CNS. Expression of both IL- $1 \beta$ and inflammasome components are increased following traumatic (de Rivero Vaccari et al., 2009) and ischemic (Abulafia et al., 2009) brain injury, and interference of inflammasome activation by administration of either ASC- or NALP1-neutralizing antibodies is able to attenuate injuryinduced production of IL-1 $\beta$ (Abulafia et al., 2009; de Rivero Vaccari et al., 2009). In addition, in a model of spinal cord injury, upregulation of IL- $1 \beta$ is prevented by an ASC-neutralizing antibody, and both functional recovery and injury volume are improved (de Rivero Vaccari et al., 2008).

Indeed, we have previously reported that LPS induces the release of IL- $1 \beta$, active caspase- 1 , and the inflammasome accessory protein ASC from microglia in the dorsal horn of the spinal cord through the ASC-caspase-1-dependent pathway (Clark et al., 2006). The current study indicates, for the first time, the involvement of a second LPS-P2X7 pathway in the secretion of IL- $1 \beta$ from spinal microglia (Fig. 8). LPS application to the spinal cord induces increases in extracellular ATP which is essential for P2X7-mediated release of IL- $1 \beta$. The sources of ATP in this model system include microglia, which contribute directly following TLR4 activation by LPS, as well as neurons and astrocytes, which may indirectly contribute to enhanced extracellular ATP levels, and therefore lead to $\mathrm{P} 2 \mathrm{X} 7$ receptor activation. This $\mathrm{P} 2 \mathrm{X} 7$-dependent pathway is still likely to activate ASC-caspase-1 complex (Di Virgilio, 2007), although it may do so in a NALP3dependent manner (Mariathasan et al., 2006). Similarly to P2X7-/- macrophages (Chessell et al., 2005), both ASC-I(Mariathasan et al., 2004, 2006) and NALP3-/- (Mariathasan et al., 2006) macrophages do not release mature IL- $1 \beta$ after ATP stimulation, suggesting that the depletion of intracellular potassium ions contributes to caspase- 1 activation. Furthermore, in macrophages the $\mathrm{P} 2 \mathrm{X} 7$ receptor may activate the inflammasome via activation of the pannexin- 1 hemichannel, which is sensitive to changes in intracellular potassium, thereby promoting the release of mature IL-1 $\beta$ (Pelegrin and Surprenant, 2006, 2007, 2009; Pelegrin et al., 2008). The mechanisms by which P2X7 receptor signaling and pannexin-1 hemichannels are linked remain unclear. However, recent work suggests that pharmacological agents that act to block P2X7, as well as ATP itself, directly suppress pannexin-1 hemichannel currents (Qiu and Dahl, 2009). The specific P2X7 antagonist A-438097 used in this study inhibited pannexin-1 hemichannel currents in oocytes alongside ATP and ATP analogs (Qiu and Dahl, 2009). However, much higher concentrations of A-438079 were required for pannexin-1 inhibition than those necessary for P2X7 inhibition (Dubyak, 2009; Qiu and Dahl, 2009). Indeed, at the concentration of $10 \mu \mathrm{M}$ A-438079, which completely inhibits IL- $1 \beta$ release in the dorsal horn, inhibition of pannexin-1 hemichannel currents was not detected (Qiu and Dahl, 2009).

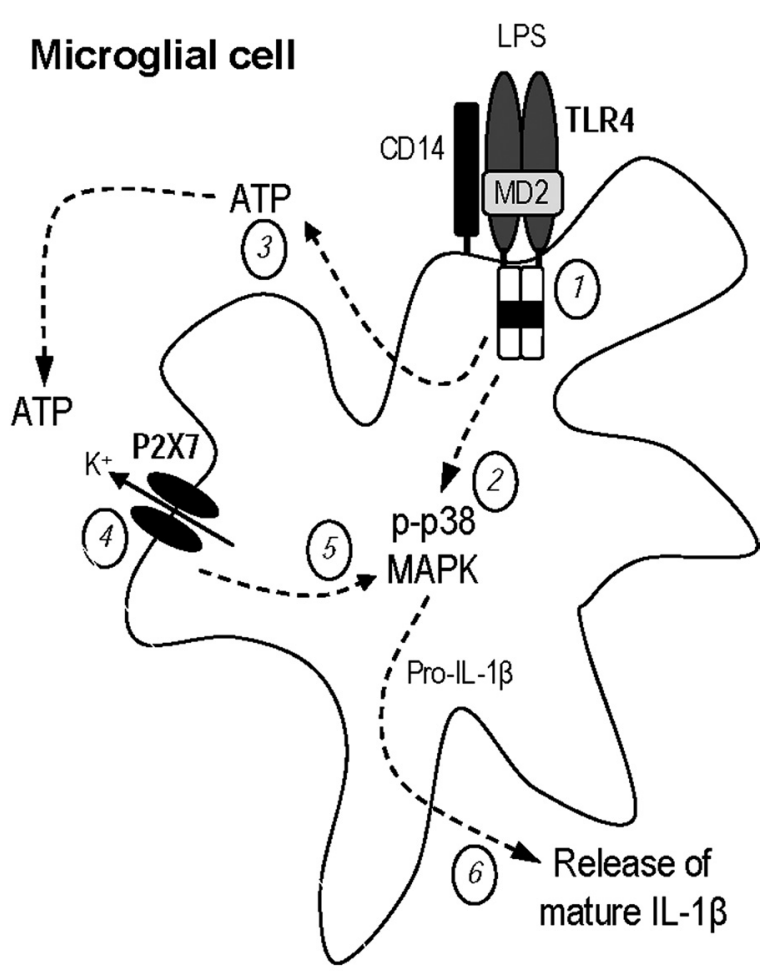

Figure 8. Schematic of proposed mechanism of P2X7-mediated IL- $1 \beta$ release from spinal microglia. LPS activates TLR4 on microglia (1), resulting in phosphorylation of 38 MAPK (2) and increased extracellular ATP (3). Other cell types may also contribute to enhanced extracellular ATP. ATP then activates P2X7 receptor signaling (4), leading to further P38 MAPK phosphorylation (5) and release of mature IL- $1 \beta(6)$.

In the dorsal horn of the spinal cord, we have observed that brief applications of LPS and ATP also induce phosphorylation of p38 MAPK in microglial cells. Similarly to IL-1 $\beta$ release, LPSinduced phosphorylation of p38 MAPK is P2X7 dependent. However, in contrast to LPS-induced IL- $1 \beta$ release, which is absent in P2X7-null mice, a significant level of p38 MAPK activation is still measurable in the dorsal horn of P2X7-null mice following LPS stimulation. Phosphorylation of p38 MAPK is also a vital downstream signaling event following the activation of many other receptors, including many P2 receptors (Inoue, 2006; Kobayashi et al., 2008), and the remaining level of phosphorylation observed is likely to occur following TLR4 activation by LPS. These data suggest that the TLR4 receptor MAPK pathways can be activated independently of $\mathrm{P} 2 \mathrm{X} 7$ receptor activation which also induces p38 MAPK activation. Such a suggestion is supported by evidence showing that phosphorylation of p38 MAPK is an intracellular event that is shared by TLR4 and P2X7 activation, leading to several events. For example, P2X7 activation modulates $\mathrm{TNF} \alpha$ release from microglia in a p38 MAPK-dependent manner (Suzuki et al., 2004). In addition to an involvement in IL-1 $\beta$ secretion from cultured immune cells (Ferrari et al., 1997; Baldassare et al., 1999; Caivano and Cohen, 2000; Kim et al., 2004; Piccini et al., 2008), LPS induces release of IL- $1 \beta$ from the dorsal horn of the spinal cord in a p38-dependent manner (Clark et al., 2006), and the cascade of events following TLR4 receptor activation includes phosphorylation of $\mathrm{p} 38$, which promotes the stabilization of induced mRNA for cytokines.

Phosphorylation of p38 MAPK in spinal microglia occurs in vivo in a number of nociceptive models (Svensson et al., 2003), including following nerve injury (Jin et al., 2003; Tsuda et al., 
2004; Ji and Suter, 2007), and p38 MAPK inhibitors effectively attenuate behavioral changes following injury (Tsuda et al., 2004). In particular, p38 MAPK phosphorylation in microglia occurs following intrathecal injection of LPS, which is associated with mechanical hypersensitivity (Clark et al., 2006), and release of IL- $1 \beta$ from spinal microglia contributes to LPS-induced hyperalgesia (Clark et al., 2006). This study demonstrates that LPS hypersensitivity is under the control of the $\mathrm{P} 2 \mathrm{X} 7$ receptor, as it can be prevented by a P2X7 antagonist and does not develop in P2X7 knock-out mice.

Indeed a role for $\mathrm{P} 2 \mathrm{X} 7$ in enhanced nociceptive transmission following injury has been demonstrated previously. P2X7 knockout mice develop reduced levels of hyperalgesia in models of inflammatory pain and do not develop hyperalgesia following peripheral nerve injury (Chessell et al., 2005). In addition, the systemic administration of specific $\mathrm{P} 2 \mathrm{X} 7$ antagonists attenuate pain behavior in models of peripheral neuropathy (Honore et al., 2006b; McGaraughty et al., 2007) and inflammatory pain (Honore et al., 2009). Modulation of chronic pain behavior by P2X7 can be partially attributed to an absence of IL- $1 \beta$ secretion from LPS stimulated peritoneal macrophages (Chessell et al., 2005; Honore et al., 2006b; McGaraughty et al., 2007; Honore et al., 2009). However, depletion of peripheral macrophages only partially reduces neuropathic hyperalgesia following peripheral nerve injury (Rutkowski et al., 2000; Barclay et al., 2007). Therefore the remaining component may be attributed to spinal P2X7 receptors expressed by activated microglial cells.

Our data suggest that spinal P2X7 receptors are equally able to regulate the secretion of mature IL- $1 \beta$ from activated microglia within the dorsal horn, and thereby contribute to behavioral hypersensitivity. We therefore suggest central P2X7 receptor may be a target for the treatment of chronic pain.

\section{References}

Abbadie C, Bhangoo S, De Koninck Y, Malcangio M, Melik-Parsadaniantz S, White FA (2009) Chemokines and pain mechanisms. Brain Res Rev 60:125-134.

Abulafia DP, de Rivero Vaccari JP, Lozano JD, Lotocki G, Keane RW, Dietrich WD (2009) Inhibition of the inflammasome complex reduces the inflammatory response after thromboembolic stroke in mice. J Cereb Blood Flow Metab 29:534-544.

Andrei C, Dazzi C, Lotti L, Torrisi MR, Chimini G, Rubartelli A (1999) The secretory route of the leaderless protein interleukin 1beta involves exocytosis of endolysosome-related vesicles. Mol Biol Cell 10:1463-1475.

Andrei C, Margiocco P, Poggi A, Lotti LV, Torrisi MR, Rubartelli A (2004) From the cover: phospholipases $\mathrm{C}$ and A2 control lysosome-mediated IL-1\{beta\} secretion: implications for inflammatory processes. Proc Natl Acad Sci U S A 101:9745-9750.

Baldassare JJ, Bi Y, Bellone CJ (1999) The role of p38 mitogen-activated protein kinase in IL-1 \{beta\} transcription. J Immunol 162:5367-5373.

Barclay J, Clark AK, Ganju P, Gentry C, Patel S, Wotherspoon G, Buxton F, Song C, Ullah J, Winter J, Fox A, Bevan S, Malcangio M (2007) Role of the cysteine protease cathepsin $S$ in neuropathic hyperalgesia. Pain 130:225-234.

Burns K, Martinon F, Tschopp J (2003) New insights into the mechanism of IL-1 [beta] maturation. Curr Opin Immunol 15:26-30.

Burnstock G (2006) Purinergic P2 receptors as targets for novel analgesics. Pharmacol Ther 110:433-454

Caivano M, Cohen P (2000) Role of mitogen-activated protein kinase cascades in mediating lipopolysaccharide-stimulated induction of cyclooxygenase-2 and IL-1 1 beta\} in RAW264 macrophages. J Immunol 164:3018-3025.

Chaplan SR, Bach FW, Pogrel JW, Chung JM, Yaksh TL (1994) Quantitative assessment of tactile allodynia in the rat paw. J Neurosci Methods 53:55-63.

Chessell IP, Hatcher JP, Bountra C, Michel AD, Hughes JP, Green P, Egerton J, Murfin M, Richardson J, Peck WL, Grahames CB, Casula MA, Yiangou Y, Birch R, Anand P, Buell GN (2005) Disruption of the P2X7 purino- ceptor gene abolishes chronic inflammatory and neuropathic pain. Pain 114:386-396.

Clark AK, D’Aquisto F, Gentry C, Marchand F, McMahon SB, Malcangio M (2006) Rapid co-release of interleukin 1beta and caspase 1 in spinal cord inflammation. J Neurochem 99:868-880.

Clark AK, Gentry C, Bradbury EJ, McMahon SB, Malcangio M (2007a) Role of spinal microglia in rat models of peripheral nerve injury and inflammation. Eur J Pain 11:223-230.

Clark AK, Yip PK, Grist J, Gentry C, Staniland AA, Marchand F, Dehvari M, Wotherspoon G, Winter J, Ullah J, Bevan S, Malcangio M (2007b) Inhibition of spinal microglial cathepsin $\mathrm{S}$ for the reversal of neuropathic pain. Proc Natl Acad Sci U S A 25:10655-10660.

Clark AK, Yip PK, Malcangio M (2009) The liberation of fractalkine in the dorsal horn requires microglial cathepsin S. J Neurosci 29:6945-6954.

Collo G, Neidhart S, Kawashima E, Kosco-Vilbois M, North RA, Buell G (1997) Tissue distribution of the P2X7 receptor. Neuropharmacology 36:1277-1283.

de Rivero Vaccari JP, Lotocki G, Marcillo AE, Dietrich WD, Keane RW (2008) A molecular platform in neurons regulates inflammation after spinal cord injury. J Neurosci 28:3404-3414.

de Rivero Vaccari JP, Lotocki G, Alonso OF, Bramlett HM, Dietrich WD, Keane RW (2009) Therapeutic neutralization of the NLRP1 inflammasome reduces the innate immune response and improves histopathology after traumatic brain injury. J Cereb Blood Flow Metab 29:1251-1261.

Di Virgilio F (2007) Liaisons dangereuses: P2X7 and the inflammasome. Trends Pharmacol Sci 28:465-472.

Dixon WJ (1980) Efficient analysis of experimental observations. Annu Rev Pharmacol Toxicol 20:441-462.

Dubyak GR (2009) Both sides now: multiple interactions of ATP with pannexin- 1 hemichannels. Focus on "A permeant regulating its permeation pore: inhibition of pannexin 1 channels by ATP.” Am J Physiol Cell Physiol 296:C235-C241.

Ferrari D, Chiozzi P, Falzoni S, Hanau S, Di Virgilio F (1997) Purinergic modulation of interleukin-1beta release from microglial cells stimulated with bacterial endotoxin. J Exp Med 185:579-582.

Ferrari D, Pizzirani C, Adinolfi E, Lemoli RM, Curti A, Idzko M, Panther E, Di Virgilio F (2006) The P2X7 receptor: a key player in IL-1 processing and release. J Immunol 176:3877-3883.

Gustafson-Vickers SL, Lu VB, Lai AY, Todd KG, Ballanyi K, Smith PA (2008) Long-term actions of interleukin-1beta on delay and tonic firing neurons in rat superficial dorsal horn and their relevance to central sensitization. Mol Pain 4:63.:63.

Honore P, Wade CL, Zhong C, Harris RR, Wu C, Ghayur T, Iwakura Y, Decker MW, Faltynek C, Sullivan J, Jarvis MF (2006a) Interleukinlalphabeta gene-deficient mice show reduced nociceptive sensitivity in models of inflammatory and neuropathic pain but not post-operative pain. Behav Brain Res 167:355-364.

Honore P, Donnelly-Roberts D, Namovic MT, Hsieh G, Zhu CZ, Mikusa JP, Hernandez G, Zhong C, Gauvin DM, Chandran P, Harris R, Medrano AP, Carroll W, Marsh K, Sullivan JP, Faltynek CR, Jarvis MF (2006b) A-740003 $[\mathrm{N}-(1-\{[$ (cyanoimino) (5-quinolinylamino) methyl $]$ amino $\}$ 2,2-dimethylpropyl)-2-(3,4-dimethoxyphenyl)acetamide], a novel and selective P2X7 receptor antagonist, dose-dependently reduces neuropathic pain in the rat. J Pharmacol Exp Ther 319:1376-1385.

Honore P, Donnelly-Roberts D, Namovic M, Zhong C, Wade C, Chandran P, Zhu C, Carroll W, Perez-Medrano A, Iwakura Y, Jarvis MF (2009) The antihyperalgesic activity of a selective P2X7 receptor antagonist, A-839977, is lost in IL- $1 \alpha \beta$ knockout mice. Behav Brain Res 204:77-81.

Inoue K (2006) The function of microglia through purinergic receptors: neuropathic pain and cytokine release. Pharmacol Ther 109:210-226.

Ji RR, Suter MR (2007) p38 MAPK, microglial signaling, and neuropathic pain. Mol Pain 3:33.

Jin SX, Zhuang ZY, Woolf CJ, Ji RR (2003) p38 mitogen-activated protein kinase is activated after a spinal nerve ligation in spinal cord microglia and dorsal root ganglion neurons and contributes to the generation of neuropathic pain. J Neurosci 23:4017-4022.

Kim SH, Smith CJ, Van Eldik LJ (2004) Importance of MAPK pathways for microglial pro-inflammatory cytokine IL-1 [beta] production. Neurobiol Aging 25:431-439.

Kobayashi K, Yamanaka H, Fukuoka T, Dai Y, Obata K, Noguchi K (2008) 
P2Y12 receptor upregulation in activated microglia is a gateway of p38 signaling and neuropathic pain. J Neurosci 28:2892-2902.

Lehnardt S, Lachance C, Patrizi S, Lefebvre S, Follett PL, Jensen FE, Rosenberg PA, Volpe JJ, Vartanian T (2002) The toll-like receptor TLR4 is necessary for lipopolysaccharide-induced oligodendrocyte injury in the CNS. J Neurosci 22:2478-2486.

MacKenzie A, Wilson HL, Kiss-Toth E, Dower SK, North RA, Surprenant A (2001) Rapid secretion of interleukin-1 [beta] by microvesicle shedding. Immunity 15:825-835.

Malcangio M, Bowery NG, Flower RJ, Perretti M (1996) Effect of interleukin-1 beta on the release of substance P from rat isolated spinal cord. Eur J Pharmacol 299:113-118.

Mariathasan S, Newton K, Monack DM, Vucic D, French DM, Lee WP, RooseGirma M, Erickson S, Dixit VM (2004) Differential activation of the inflammasome by caspase-1 adaptors ASC and Ipaf. Nature 430:213-218.

Mariathasan S, Weiss DS, Newton K, McBride J, O’Rourke K, Roose-Girma M, Lee WP, Weinrauch Y, Monack DM, Dixit VM (2006) Cryopyrin activates the inflammasome in response to toxins and ATP. Nature 440:228-232.

Martinon F, Tschopp J (2004) Inflammatory caspases: linking an intracellular innate immune system to autoinflammatory diseases. Cell 117:561-574.

Martinon F, Burns K, Tschopp J (2002) The inflammasome: a molecular platform triggering activation of inflammatory caspases and processing of proIL-[beta]. Mol Cell 10:417-426.

McGaraughty S, Chu KL, Namovic MT, Donnelly-Roberts DL, Harris RR, Zhang XF, Shieh CC, Wismer CT, Zhu CZ, Gauvin DM, Fabiyi AC, Honore P, Gregg RJ, Kort ME, Nelson DW, Carroll WA, Marsh K, Faltynek CR, Jarvis MF (2007) P2X7-related modulation of pathological nociception in rats. Neuroscience 146:1817-1828.

McMahon SB, Malcangio M (2009) Current challenges in glia-pain biology. Neuron 64:46-54.

Medzhitov R (2008) Origin and physiological roles of inflammation. Nature 454:428-435.

Milligan ED, Watkins LR (2009) Pathological and protective roles of glia in chronic pain. Nat Rev Neurosci 10:23-36.

Pelegrin P, Surprenant A (2006) Pannexin-1 mediates large pore formation and interleukin-1beta release by the ATP-gated P2X7 receptor. EMBO J 25:5071-5082.

Pelegrin P, Surprenant A (2007) Pannexin-1 couples to maitotoxin- and nigericin-induced interleukin-1beta release through a dye uptakeindependent pathway. J Biol Chem 282:2386-2394.

Pelegrin P, Surprenant A (2009) The P2X(7) receptor-pannexin connection to dye uptake and IL-1beta release. Purinergic Signal 5:129-137.

Pelegrin P, Barroso-Gutierrez C, Surprenant A (2008) P2X7 receptor differentially couples to distinct release pathways for IL-1 $\{$ beta $\}$ in mouse macrophage. J Immunol 180:7147-7157.

Piccini A, Carta S, Tassi S, Lasiglié D, Fossati G, Rubartelli A (2008) ATP is released by monocytes stimulated with pathogen-sensing receptor ligands and induces IL- $1 \beta$ and IL-18 secretion in an autocrine way. Proc Natl Acad Sci U S A 105:8067-8072.

Qiu F, Dahl G (2009) A permeant regulating its permeation pore: inhibition of pannexin 1 channels by ATP. Am J Physiol Cell Physiol 296:C250-C255.

Reeve AJ, Patel S, Fox A, Walker K, Urban L (2000) Intrathecally administered endotoxin or cytokines produce allodynia, hyperalgesia and changes in spinal cord neuronal responses to nociceptive stimuli in the rat. Eur J Pain 4:247-257.

Rubartelli A, Cozzolino F, Talio M, Sitia R (1990) A novel secretory pathway for interleukin-1 beta, a protein lacking a signal sequence. EMBO J 9:1503-1510.

Rutkowski MD, Pahl JL, Sweitzer S, van Rooijen N, DeLeo JA (2000) Limited role of macrophages in generation of nerve injury-induced mechanical allodynia. Physiol Behav 71:225-235.

Sung CS, Wen ZH, Chang WK, Ho ST, Tsai SK, Chang YC, Wong CS (2004) Intrathecal interleukin-1 [beta] administration induces thermal hyperalgesia by activating inducible nitric oxide synthase expression in the rat spinal cord. Brain Res 1015:145-153.

Suzuki T, Hide I, Ido K, Kohsaka S, Inoue K, Nakata Y (2004) Production and release of neuroprotective tumor necrosis factor by $\mathrm{P} 2 \mathrm{X} 7$ receptoractivated microglia. J Neurosci 24:1-7.

Svensson CI, Marsala M, Westerlund A, Calcutt NA, Campana WM, Freshwater JD, Catalano R, Feng Y, Protter AA, Scott B, Yaksh TL (2003) Activation of p38 mitogen-activated protein kinase in spinal microglia is a critical link in inflammation-induced spinal pain processing. J Neurochem 86:1534-1544.

Tanga FY, Nutile-McMenemy N, DeLeo JA (2005) The CNS role of Tolllike receptor 4 in innate neuroimmunity and painful neuropathy. Proc Natl Acad Sci U S A 102:5856-5861.

Tsuda M, Shigemoto-Mogami Y, Koizumi S, Mizokoshi A, Kohsaka S, Salter MW, Inoue K (2003) P2X4 receptors induced in spinal microglia gate tactile allodynia after nerve injury. Nature 424:778-783.

Tsuda M, Mizokoshi A, Shigemoto-Mogami Y, Koizumi S, Inoue K (2004) Activation of p38 mitogen-activated protein kinase in spinal hyperactive microglia contributes to pain hypersensitivity following peripheral nerve injury. Glia 45:89-95.

Wolf G, Gabay E, Tal M, Yirmiya R, Shavit Y (2006) Genetic impairment of interleukin-1 signaling attenuates neuropathic pain, autotomy, and spontaneous ectopic neuronal activity, following nerve injury in mice. Pain 120:315-324.

Yamamoto M, Yamazaki S, Uematsu S, Sato S, Hemmi H, Hoshino K, Kaisho T, Kuwata H, Takeuchi O, Takeshige K, Saitoh T, Yamaoka S, Yamamoto N, Yamamoto S, Muta T, Takeda K, Akira S (2004) Regulation of Toll/ IL-1-receptor-mediated gene expression by the inducible nuclear protein I[kappa]B[zeta]. Nature 430:218-222.

Yip PK, Kaan TK, Fenesan D, Malcangio M (2009) Rapid isolation and culture of primary microglia from adult mouse spinal cord. J Neurosci Methods 183:223-237. 